\title{
Crystallization Behavior of Phosphate Glasses with Hydrophobic Coating Materials
}

\author{
Jaeyeop Chung and Bongki Ryu \\ Department of Materials Science and Engineering, Pusan National University, Busan 609-735, Republic of Korea \\ Correspondence should be addressed to Bongki Ryu; bkryu@pusan.ac.kr
}

Received 20 March 2015; Revised 8 May 2015; Accepted 18 May 2015

Academic Editor: Zijie Yan

Copyright ( 2015 J. Chung and B. Ryu. This is an open access article distributed under the Creative Commons Attribution License, which permits unrestricted use, distribution, and reproduction in any medium, provided the original work is properly cited.

\begin{abstract}
We analyzed the effect of the addition of $\mathrm{Li}_{2} \mathrm{O}_{3}, \mathrm{TiO}_{2}$, and $\mathrm{Fe}_{2} \mathrm{O}_{3}$ on the crystallization behavior of $\mathrm{P}_{2} \mathrm{O}_{5}-\mathrm{CaO}-\mathrm{SiO}_{2}-\mathrm{K}_{2} \mathrm{O}$ glasses and the effect of the crystallization behavior on the roughness and hydrophobicity of the coated surface. Exothermic behavior, including a strong exothermic peak in the 833-972 $\mathrm{K}$ temperature range when $\mathrm{Fe}_{2} \mathrm{O}_{3}, \mathrm{TiO}_{2}$, or $\mathrm{Li}_{2} \mathrm{O}_{3}$ was added, was confirmed by differential thermal analysis. The modified glass samples (PFTL1-3) showed diffraction peaks when heated at 1073 and $1123 \mathrm{~K}$ for $5 \mathrm{~min}$; the crystallized phase corresponds to $\mathrm{Fe}_{3}\left(\mathrm{PO}_{4}\right)_{2}$, that is, graftonite. We confirmed that the intensity of the diffraction peaks increases at high temperatures and with increasing $\mathrm{Li}_{2} \mathrm{O}_{3}$ content. In the case of the PFTL3 glass, a $\mathrm{Li}_{3} \mathrm{Fe}_{2}\left(\mathrm{PO}_{4}\right)_{2}$ phase, that is, trilithium diiron(III) tris[phosphate $(\mathrm{V})]$, was observed. Through scanning electron microscopy and the contact angles of the surfaces with water, we confirmed that the increase in surface roughness, correlated to the crystallization of the glass frit, increases hydrophobicity of the surface. The calculated values of the local activation energies for the growth of $\mathrm{Fe}_{3}\left(\mathrm{PO}_{4}\right)_{2}$ on the PTFL1, PTFL2, and PFTL3 glass were $237-292 \mathrm{~kJ} \mathrm{~mol}^{-1}, 182-258 \mathrm{~kJ} \mathrm{~mol}^{-1}$, and $180-235 \mathrm{~kJ} \mathrm{~mol}^{-1}$.
\end{abstract}

\section{Introduction}

Hydrophobic and superhydrophobic solid surfaces have attracted considerable attention in scientific and industrial fields owing to their unique self-cleaning, antifogging, antisticking, and anticontamination properties [1-5]. It has been theoretically and experimentally confirmed that superhydrophobic surfaces can be obtained by the cooperative effects of topographically roughened surface structures [6]. In accordance with this concept, researchers have prepared artificial superhydrophobic surfaces through hierarchical micro/nanostructures on specimen surfaces $[6,7]$ and have chemically modified these structures to reduce the surface energy [8]. Various methods have been reported for creating superhydrophobic surfaces, such as sol-gel processing [9], plasma processing [10], and spray pyrolysis [11]. However, these methods present limitations for industrial applications and are unsuitable for commercial products because they either are only applicable to small substrates or require time-consuming processing steps or expensive machinery [12]. Recently, studies have been performed to overcome these problems. In particular, Reinosa et al. confirmed the influence of surface modification by crystallization on the hydrophobicity of surfaces, which occurs during the inorganic coating of glass frit by $\mathrm{Fe}_{2} \mathrm{O}_{3}$ and $\mathrm{Cu}$ microparticles [12]. They confirmed that the surface was modified and the hydrophobicity increased through the crystallization of the inorganic coating material. However, they only analyzed the crystallization generated by the addition of $\mathrm{Fe}_{2} \mathrm{O}_{3}$ and $\mathrm{Cu}$ microparticles, neglecting crystallization by the composition of the glass frit itself. If hydrophobicity can be expressed just by the crystallization of glass frit, this can be used in various applications such as self-cleaning household ovens $[13,14]$ and outdoor glass insulators [15].

Phosphate glass exhibits attractive properties such as low glass transition and melting temperatures, high thermal expansion coefficients, biocompatibility, and high refractive indices. These specifications are suitable for many applications in photonics, fast ion conductors [16-19], glass-tometal seals [20-22], low-temperature enamels [22], $\mathrm{NH}_{3}$ gas adsorption [23], and biomedical engineering [24]. An important characteristic of phosphate glass is its advantageous 
TABLE 1: The chemical compositions of the PFTL glass samples.

\begin{tabular}{|c|c|c|c|c|c|c|c|}
\hline Glass name & $\mathrm{P}_{2} \mathrm{O}_{5}(\mathrm{wt} \%)$ & $\mathrm{CaO}(\mathrm{wt} \%)$ & $\mathrm{SiO}_{2}(\mathrm{wt} \%)$ & $\mathrm{K}_{2} \mathrm{O}(\mathrm{wt} \%)$ & $\mathrm{TiO}_{2}(w \mathrm{t} \%)$ & $\mathrm{Fe}_{2} \mathrm{O}_{3}(\mathrm{wt} \%)$ & $\mathrm{Li}_{2} \mathrm{O}(\mathrm{wt} \%)$ \\
\hline PFTL0 (reference) & 74 & 14 & 5 & 7 & 0 & 0 & 0 \\
\hline PFTL1 & 65.1 & 12.3 & 4.4 & 6.2 & 5 & 5 & 2 \\
\hline PFTL2 & 64.4 & 12.2 & 4.3 & 6.1 & 5 & 5 & 3 \\
\hline PFTL3 & 63.7 & 12.0 & 4.3 & 6.0 & 5 & 5 & 4 \\
\hline
\end{tabular}

crystallization behavior as compared to silicate glass [25, 26]. To further accelerate the crystallization of phosphate glass, nucleation agents such as $\mathrm{Fe}_{2} \mathrm{O}_{3}$ [27], $\mathrm{Li}_{2} \mathrm{O}_{3}$, and $\mathrm{TiO}_{2}$ [28] are required; when the frit is coated with one of these agents, the glass can be crystallized using a short firing time [27].

In the present work, we investigated the effect of the addition of $\mathrm{Li}_{2} \mathrm{O}_{3}, \mathrm{TiO}_{2}$, and $\mathrm{Fe}_{2} \mathrm{O}_{3}$ on the crystallization behavior of a $\mathrm{P}_{2} \mathrm{O}_{5}-\mathrm{CaO}-\mathrm{SiO}_{2}-\mathrm{K}_{2} \mathrm{O}$ glass system widely used in various fields $[29,30]$. In addition, we confirmed the effect of the crystallization of the glass frit on the roughness and hydrophobicity of the final coated surface.

\section{Materials and Methods}

2.1. Glass Preparation. Glass samples with this composition $(100-x-y)\left(0.74 \mathrm{P}_{2} \mathrm{O}_{5}-0.14 \mathrm{CaO}-0.05 \mathrm{SiO}_{2}-0.07 \mathrm{~K}_{2} \mathrm{O}\right)-x$ $\left(\mathrm{Fe}_{2} \mathrm{O}_{3}-\mathrm{TiO}_{2}\right)-y\left(\mathrm{Li}_{2} \mathrm{O}_{3}\right)$ were used. The glass samples were prepared using $\mathrm{NH}_{4} \mathrm{H}_{2} \mathrm{PO}_{4}, \mathrm{CaCO}_{3}, \mathrm{SiO}_{2}, \mathrm{~K}_{2} \mathrm{CO}_{3}, \mathrm{Fe}_{2} \mathrm{O}_{3}$, $\mathrm{TiO}_{2}$, and $\mathrm{Li}_{2} \mathrm{CO}_{3}$, all of which had purities higher than 99.9\%. This mixture was melted in an $\mathrm{Al}_{2} \mathrm{O}_{3}$ crucible in an electrically heated furnace under ordinary atmospheric conditions at a temperature of $850^{\circ} \mathrm{C}$ for approximately $30 \mathrm{~min}$ to evaporate ammonia, carbonate, and water and to minimize the tendency for subsequent phosphate volatilization. The temperature was then gradually increased to $1250^{\circ} \mathrm{C}$ and maintained for $30 \mathrm{~min}$ to homogenize the melt. The melt was quenched by pouring it onto a plate. X-ray diffraction (XRD) analysis using an Ultima IV system (Rigaku) was employed to confirm the amorphous state of the synthesized glasses and the results are shown in Figure 1 and Table 1.

2.2. Measurements and Analysis. The glass frits were coated by the following procedure. The glass was ground and screened with a $44 \mu \mathrm{m}$ mesh and then sprayed onto the surface of a low-carbon steel substrate (SPP steel), producing coatings with thicknesses of 200-220 $\mu \mathrm{m}$. The coatings were fast-fired in an air atmosphere using an electrically heated furnace. The coating thickness of each sample is shown in Figure 2. The heating temperatures of $1073 \mathrm{~K}$ and $1123 \mathrm{~K}$ were applied for $5 \mathrm{~min}$, which is a typical enamel sintering cycle. The phase analysis and crystallization of the heated samples were examined by XRD (Rigaku-Ultima IV). To determine the surfaces' hydrophilicity or hydrophobicity, a contact angle measurement system (Krüss DSA 100 Easy Drop) was used to find the contact angle of water with the coated surfaces. The roughness and nano- and microstructures were studied by field emission scanning electron microscopy (FE-SEM, Supra 25, Carl Zeiss).

Crystallization analysis was performed by a nonisothermal method that is easier and faster than the isothermal

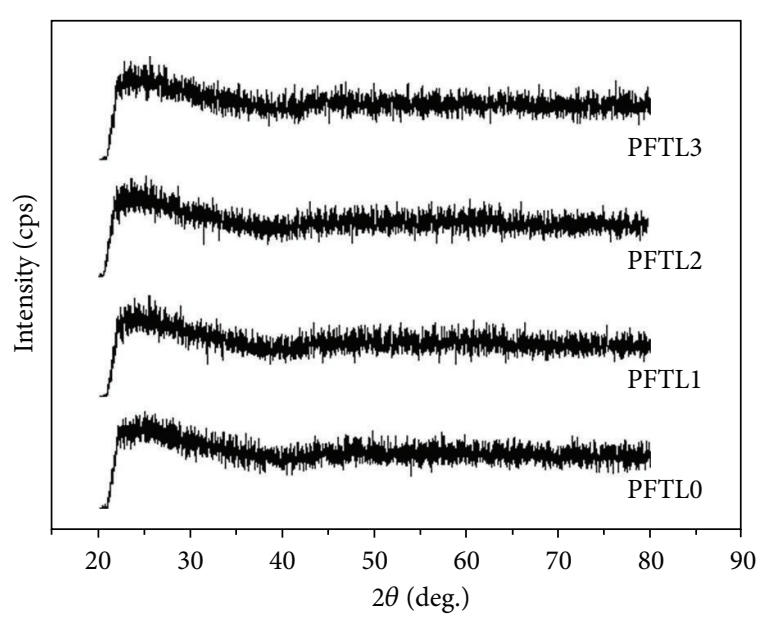

FIGURE 1: XRD data of PFTL glasses.

method $[31,32]$. In order to determine the activation energy for crystallization of the samples, differential thermal analysis (DTA) measurements were performed using approximately $30 \mathrm{mg}$ of the heat-treated glass powders in an air atmosphere at heating rates of $5,10,15$, and $20 \mathrm{~K} / \mathrm{min}$ up to $1273 \mathrm{~K}$. The DTA results were further analyzed to obtain the activation energy values for the crystallization of each sample using the Ozawa [33] method. The slope of each graph was determined by the method of least squares.

\section{Results and Discussion}

3.1. Crystallization Behavior and Phase Analysis. The DTA curves for the glass powders obtained at different heating rates are presented in Figure 3. The DTA curves show the exothermic effect of heating, followed by a strong exothermic peak in the 833-972 $\mathrm{K}$ temperature range when $\mathrm{Fe}_{2} \mathrm{O}_{3}, \mathrm{TiO}_{2}$, or $\mathrm{Li}_{2} \mathrm{O}_{3}$ is added. Furthermore, the DTA curves of the PFTL3 glass show an initial exothermic effect followed by a strong exothermic peak; Figure 3(c) also shows partial overlapping of the two peaks. The characteristic temperatures of the glass $\left(T_{g}, T_{c}\right.$, and $\left.T_{p}\right)$ increased with increasing heating rate, as shown in Table 2. From Table 2, it is confirmed that $T_{g}$ decreases with the addition of $\mathrm{Fe}_{2} \mathrm{O}_{3}$ or $\mathrm{TiO}_{2}$. This means that $\mathrm{Fe}_{2} \mathrm{O}_{3}$ and $\mathrm{TiO}_{2}$ act as network modifiers in phosphate glass and that they weaken the glass structure. In addition, the DTA data reveal that the addition of $\mathrm{Li}_{2} \mathrm{O}_{3}$ shifts the endothermic peaks to lower temperatures; that is, a lower temperature is needed to initiate crystallization [34]. 

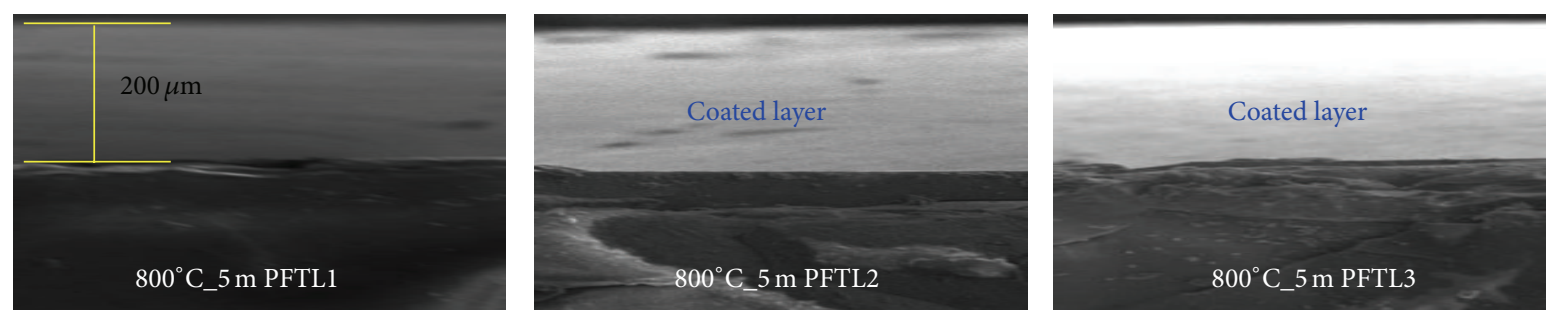

Figure 2: The coating thicknesses of PFTL glasses.

TABLE 2: Glass transition temperature $\left(T_{g}\right)$ and maximum crystallization temperatures $\left(T_{p 1}\right.$ and $\left.T_{p 2}\right)$ determined from DTA data obtained at different heating rates.

\begin{tabular}{lcccccccc}
\hline \multirow{2}{*}{ Heating rate, $\alpha$} & PFTL0 & \multicolumn{2}{c}{ PFTL1 } & \multicolumn{2}{c}{ PFTL2 } & \multicolumn{2}{c}{ PFTL3 } \\
& $T_{g}(\mathrm{~K})$ & $T_{g}(\mathrm{~K})$ & $T_{p 1}(\mathrm{~K})$ & $T_{g}(\mathrm{~K})$ & $T_{p 1}(\mathrm{~K})$ & $T_{g}(\mathrm{~K})$ & $T_{p 1}(\mathrm{~K})$ & $T_{p 2}(\mathrm{~K})$ \\
\hline 5 & 878 & 833 & 943 & 819 & 927 & 810 & 902 \\
10 & 883 & 839 & 962 & 830 & 945 & 822 & 921 \\
15 & 891 & 847 & 975 & 839 & 958 & 835 & 931 \\
20 & 903 & 861 & 984 & 853 & 968 & 847 & 963 \\
\hline
\end{tabular}

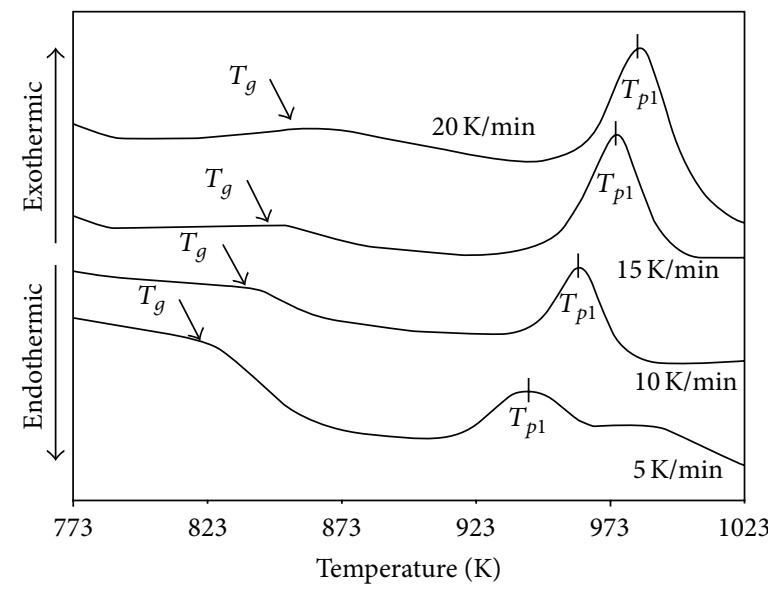

(a) PFTL1

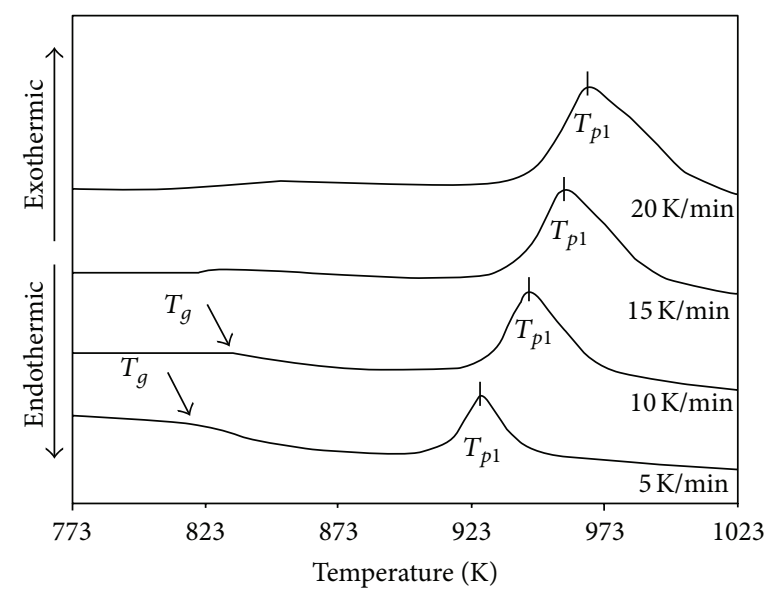

(b) PFTL2

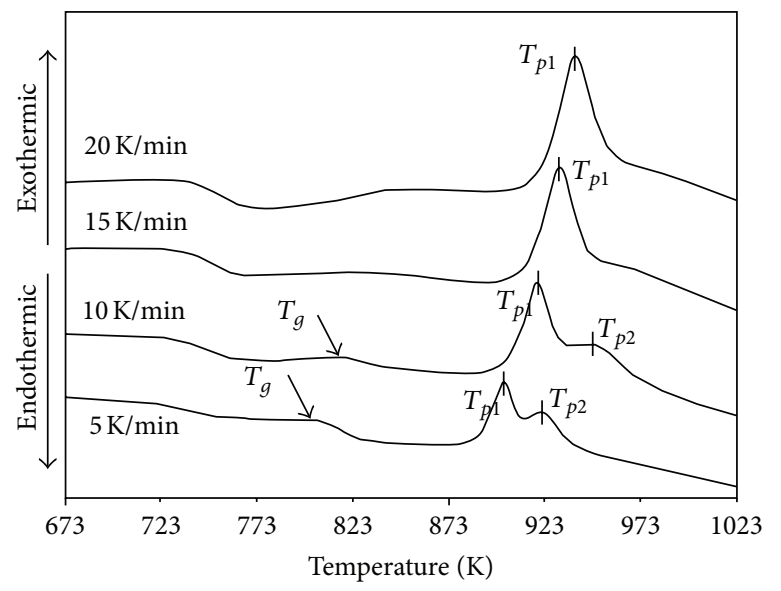

(c) PFTL3

FIGURE 3: DTA curves of PFTL glasses obtained at different heating rates. 


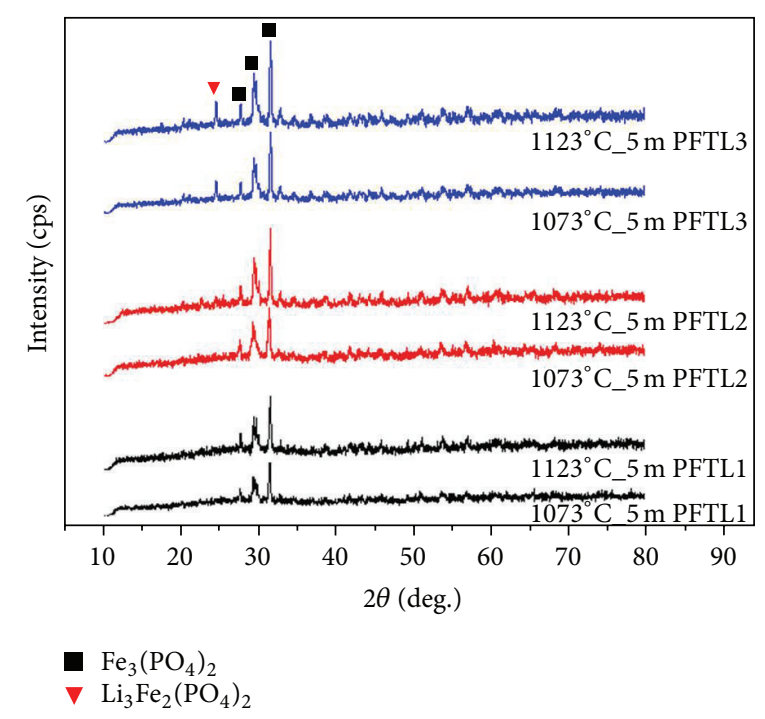

FIGURE 4: XRD data for glass samples heat-treated at different temperatures.
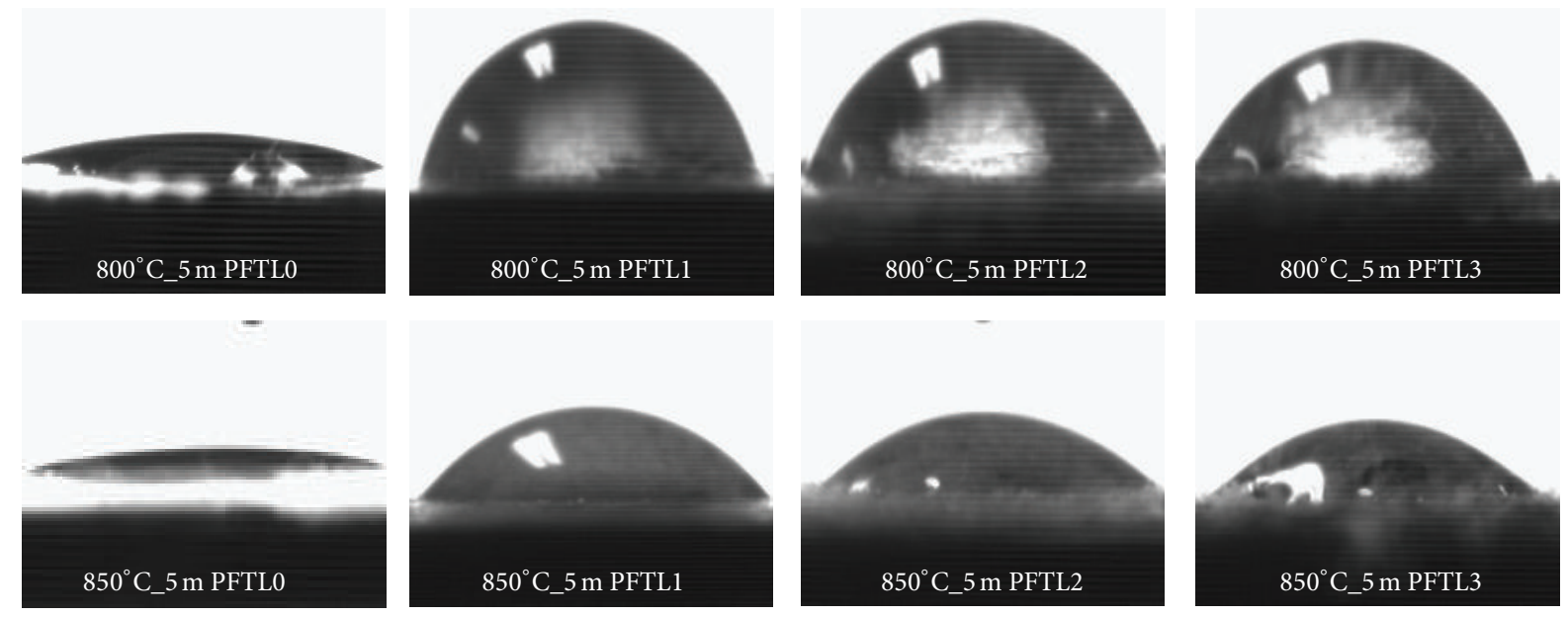

FIGURE 5: Hydrophobicity of PFTL glasses heat-treated at different temperatures, displayed by contact angle of water droplet.

To confirm the nucleation results of the DTA curves, XRD analysis was performed. Figure 4 presents the XRD patterns for glass samples heated for $5 \mathrm{~min}$ at both $1073 \mathrm{~K}$ and $1123 \mathrm{~K}$. The PFTL1-3 glass samples all show diffraction peaks; the crystalline phase corresponds to the compound $\mathrm{Fe}_{3}\left(\mathrm{PO}_{4}\right)_{2}$, that is, graftonite. The data confirms that the intensity of the diffraction peaks increases at higher heating temperatures and with increased $\mathrm{Li}_{2} \mathrm{O}_{3}$ content. In addition, in the case of the PFTL3 glass, a $\mathrm{Li}_{3} \mathrm{Fe}_{2}\left(\mathrm{PO}_{4}\right)_{2}$ phase is observed. This indicates that further crystallization occurs at higher temperature and with increased $\mathrm{Li}_{2} \mathrm{O}_{3}$ content. Through XRD analysis, we confirmed that the two exothermic peaks in the DTA curves are the result of crystal phases of $\mathrm{Fe}_{3}\left(\mathrm{PO}_{4}\right)_{2}$ (peak 1 of PFTL1, PFTL2, and PFTL3) and $\mathrm{Li}_{3} \mathrm{Fe}_{2}\left(\mathrm{PO}_{4}\right)_{2}$ (peak 2 of PFTL3).

3.2. Hydrophobicity and Surface Characteristics. The contact angle of a water drop was measured for the glass samples of different compositions and coating conditions; the results are shown in Figures 5 and 6.

As seen in the figures, the noncrystalline PFTL0 glass, that is, a typical phosphate glass, has very strong hydrophilicity; this is expected from the chemical composition of phosphate glass. The phosphate group is negatively charged, making the head polar. The phosphate heads are thus attracted to the water molecules in their environment. For these reasons, phosphate glasses have strong hydrophilicity [35]. As the glass crystallized, the contact angle increased up to a maximum of approximately $87^{\circ}$, obtained with PFTL1. In addition, the PFTL2 and PFTL3 glasses, which were more thoroughly crystallized, had lower hydrophobicity than the PFTL1 glass; all glass samples heated at $850^{\circ} \mathrm{C}$ had lower contact angles than the glass samples heated at $800^{\circ} \mathrm{C}$. These results were analyzed through surface characteristics.

For solids, the term "surface energy" reflects the affinity of the surface to other materials; the higher the surface energy 


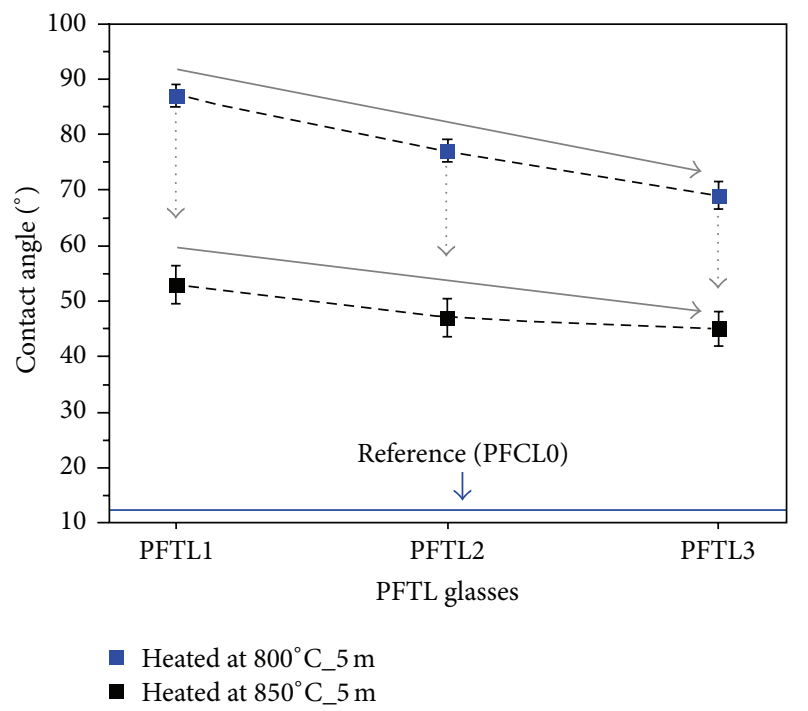

FIGURE 6: The contact angles of the PFTL glasses.

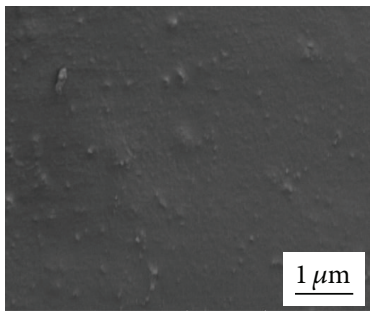

(a)

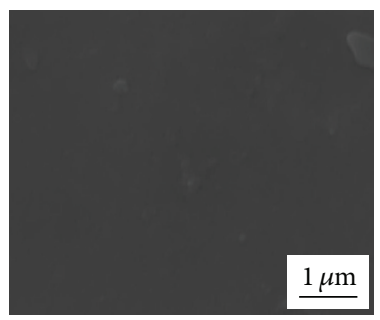

(e)

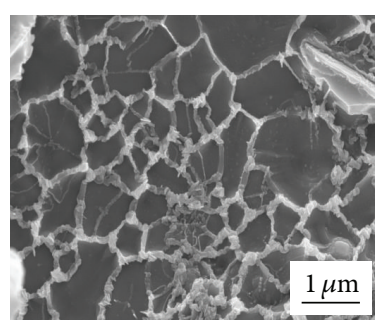

(b)

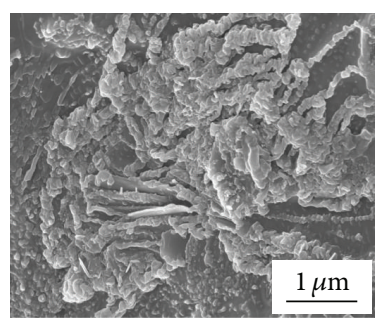

(f)

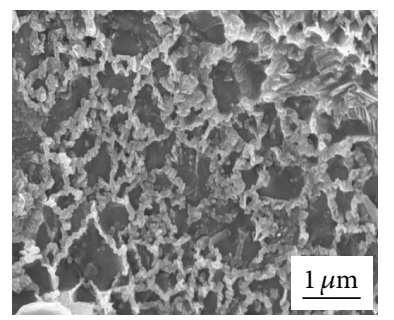

(c)

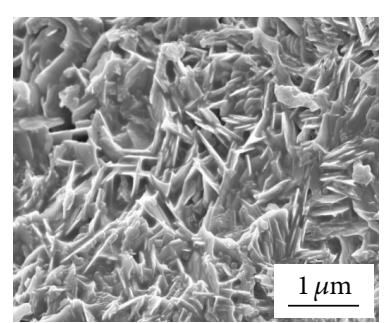

(g)

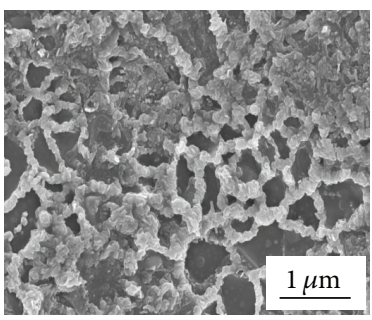

(d)

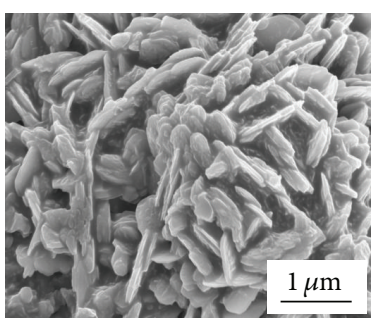

(h)

Figure 7: SEM images of PFTL glasses heated under different conditions: (a) PFTL0, (b) PFTL1, (c) PFTL2, and (d) PFTL3 glasses heated at $800^{\circ} \mathrm{C}$ for $5 \mathrm{~min}$ and (e) PFTL0, (f) PFTL1, (g) PFTL2, and (h) PFTL3 glasses heated at $850^{\circ} \mathrm{C}$ for 5 min.

of the solid, the more the energy gained upon bringing this surface into contact with other materials. Therefore, the surface energy describes the adhesive properties of the material, which can be "activated" by different surface treatments or by changing the material chemistry.

According to Abou Neel et al., the total surface free energy of phosphate glass is very high, more than $75 \mathrm{mN} \mathrm{m}^{-1}[36$, 37]. This is because of the polar characteristics of phosphate glasses, as mentioned above.

When $\mathrm{Fe}_{2} \mathrm{O}_{3}$ or $\mathrm{TiO}_{2}$ is added to the phosphate glass, the surface energy of the glass is reduced $[36,37]$. The reason for this is associated with the formation of hydration-resistant $\mathrm{Ti}-\mathrm{O}-\mathrm{P}$ and $\mathrm{Fe}-\mathrm{O}-\mathrm{P}$ bonding in place of hydration-susceptible $\mathrm{P}-\mathrm{O}-\mathrm{P}$ bonding. The hydrophobicity of the coated glass surfaces was further analyzed by surface morphology.

SEM micrographs of the PFTL glass samples heated at 800 and $850^{\circ} \mathrm{C}$ for $5 \mathrm{~min}$ are shown in Figure 7 . We can determine the causes of changes of hydrophobicity of the PFTL glasses from these micrographs. The typical phosphate sample, PFTL0, shows a flat surface very similar to those usually found on commercial enamels. PFTL1-3 heated at $800^{\circ} \mathrm{C}$ for $5 \mathrm{~min}$ have pseudocellular structures (hereafter, cellular regions) resembling those found on the surface of hydrophobic leaves $[12,38]$. Thus, hydrophobicity increases when the glass crystallizes. We think that PFTL2 and PFTL3 


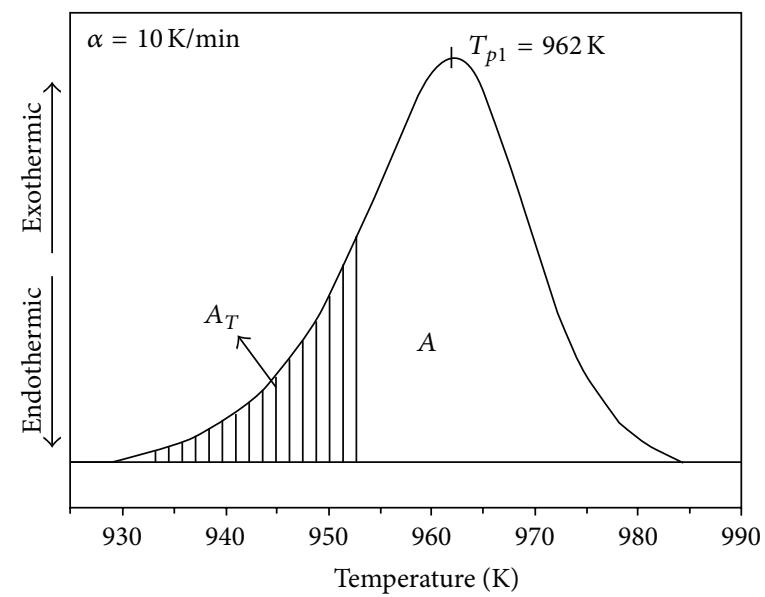

Figure 8: Area $A$ between $T_{i}$ and $T_{f}$ and area $A_{T}$ between $T_{i}$ and $T$ for the crystallization peak of the PFTL1 glass $(\alpha=10 \mathrm{~K} / \mathrm{min})$.

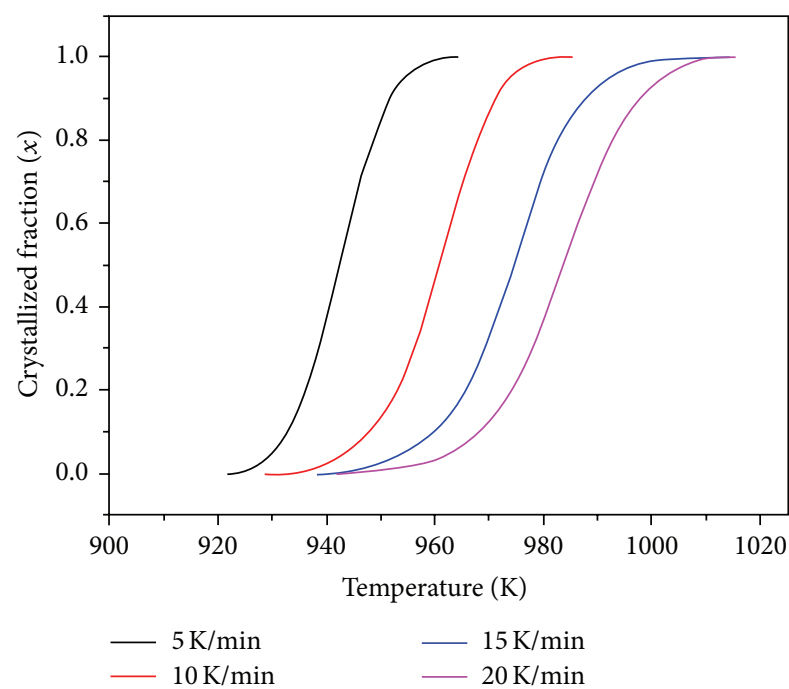

(a) PFTL1

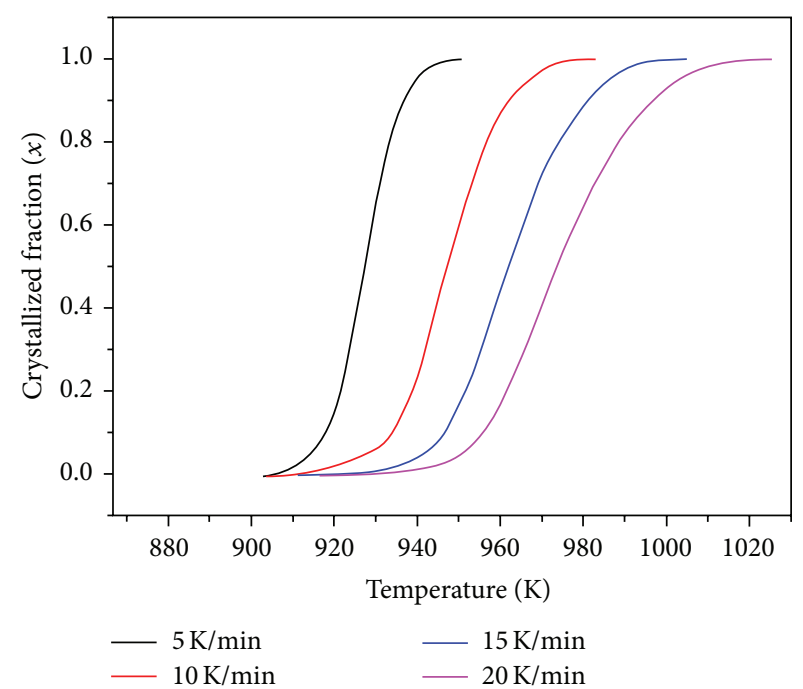

(b) PFTL2

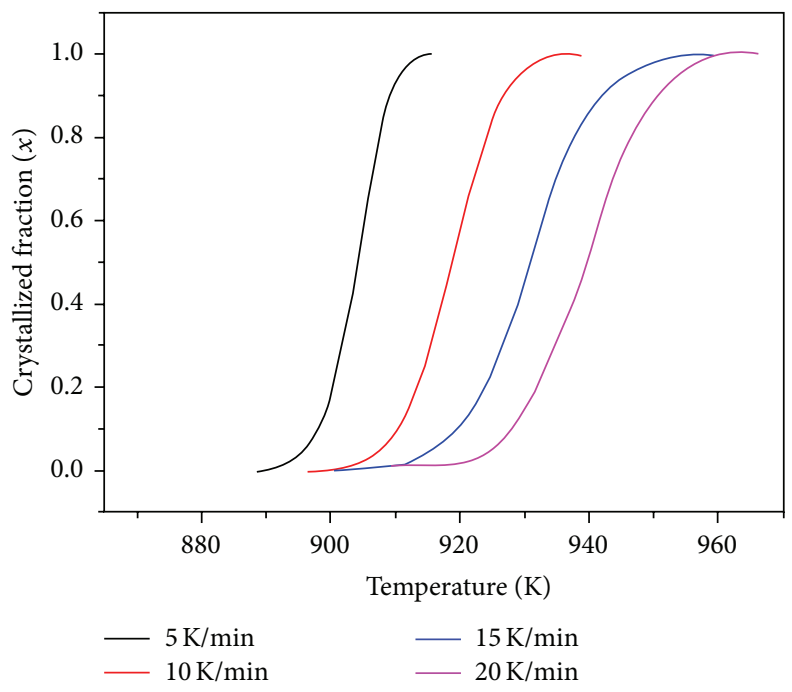

(c) PFTL3

Figure 9: Crystallized fraction as a function of temperature at different heating rates. 


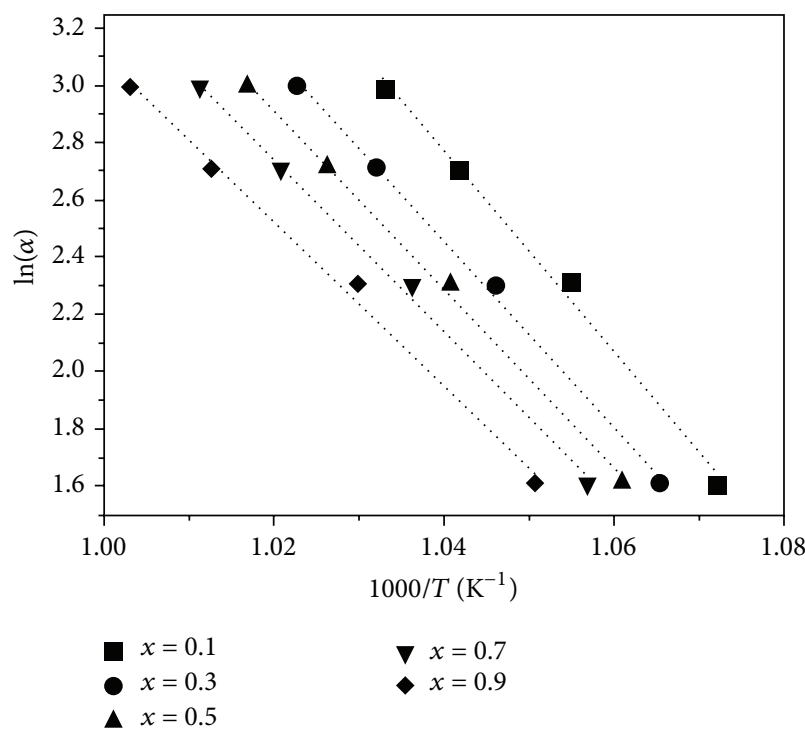

(a) PFTL1

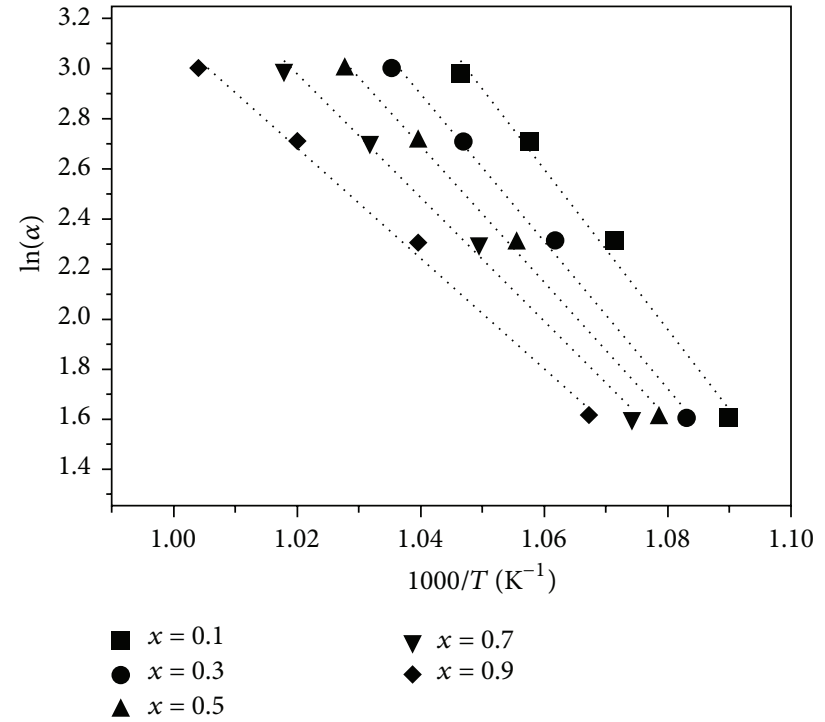

(b) PFTL2

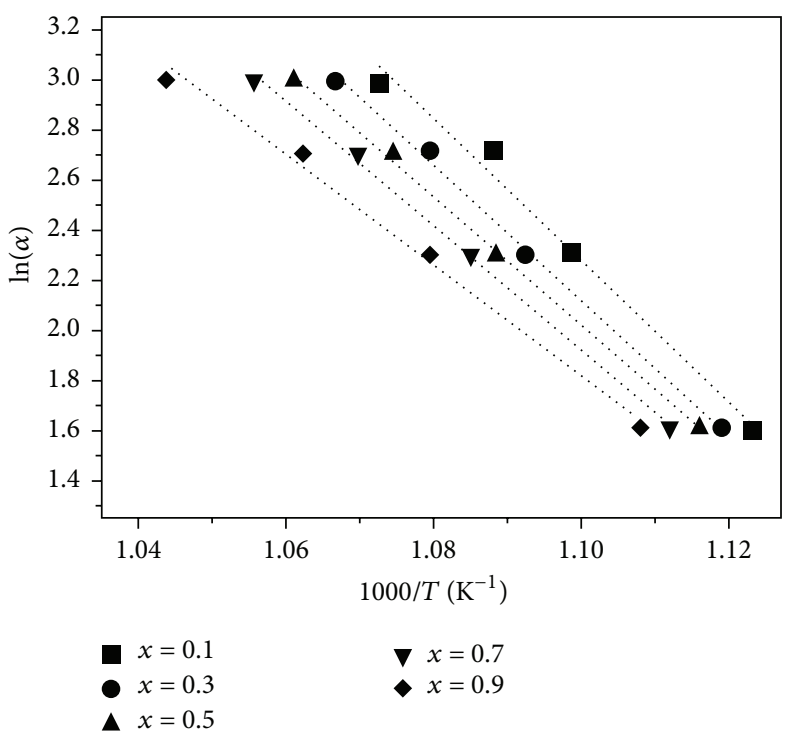

(c) PFTL3

FIGURE 10: Plots of $\ln (\alpha)$ versus $1000 / T$ for various values of $x(0.1<x<0.9)$ for the $\mathrm{Fe}_{3}\left(\mathrm{PO}_{4}\right)_{2}$ crystallization peaks.

exhibited lower hydrophobicity than PFTL1 owing to the increase in the size of the nanostructures and the corresponding reduced fraction of intergranular surface voids under the water drop. As previously demonstrated, a higher fraction of empty space below the water drop increases the contact angle, making the surface more hydrophobic [39]. In addition, PFTL1- 3 heated at $850^{\circ} \mathrm{C}$ for $5 \mathrm{~min}$ presented rough surfaces completely covered in crystalline phases owing to the high crystallization of these glasses. It is thought that these rough surfaces induced low hydrophobicity. We confirmed that the increase in surface roughness occurring by the crystallization of the glass frit increased the hydrophobicity of the surface through the analysis of hydrophobicity and surface characterization. However, the contact angle with water never exceeded $90^{\circ}$, which is the general standard for hydrophobic materials. This is thought to be because of the strong hydrophilic nature of phosphate glasses, as previously described.

3.3. Crystallization Kinetics. We analyzed the activation energy for the crystallization of the glass samples in order to verify the impact of surface crystalline phase on the hydrophobicity. The activation energy was calculated only for the $\mathrm{Fe}_{3}\left(\mathrm{PO}_{4}\right)_{2}$ phase of the PTFL1, PTFL2, and PFTL3 glasses.

The Johnson-Mehl-Avrami (JMA) model, which is the most general method of calculating activation energies, implies that the activation energy, $E_{c}$, should be constant during the transformation process [40]. However, some authors have shown that $E_{c}$ values are not necessarily constant; instead, they vary during the transformation in 


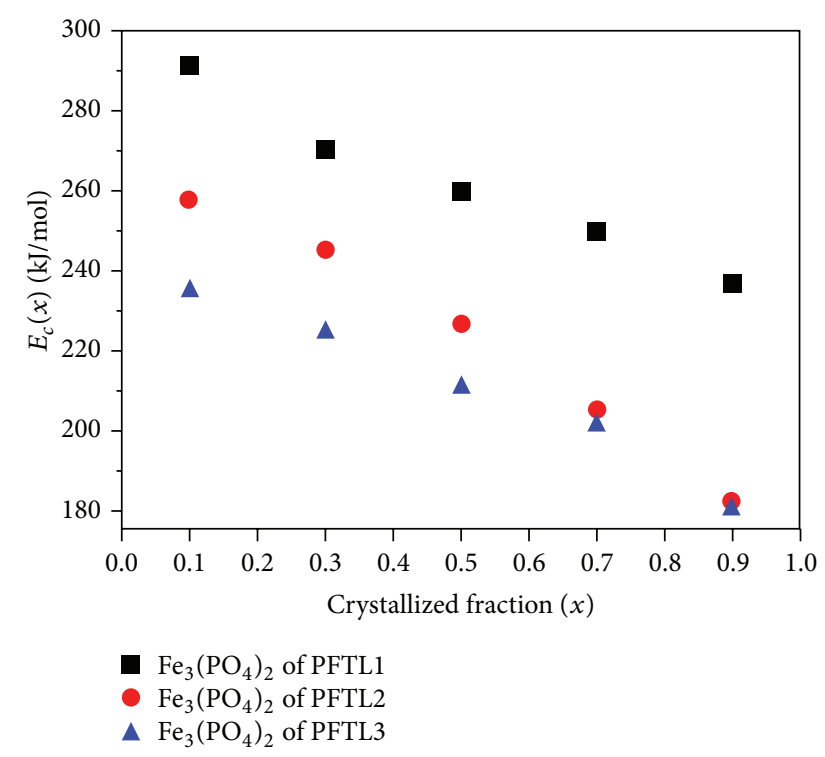

FIGURE 11: Local activation energy for crystallization $E_{c}(x)$ as a function of crystallized fraction $(x)$, obtained from the DTA curve at $10 \mathrm{~K} / \mathrm{min}$.

nonisothermal methods [41]. The activation energy for different crystallization volume fractions is not constant during the whole transformation owing to changes in the nucleation and growth behaviors during crystallization [41]. The variation of $E_{c}$ can be expressed by the local activation energy $E_{c}(x)$. The value of $E_{c}(x)$ can be determined from nonisothermal DTA results using the method proposed by Ozawa according to the following relationship [41]:

$$
\left[\frac{d(\ln \alpha)}{d(1 / T)}\right] x=-\frac{E_{c}(x)}{R},
$$

where $R$ is the gas constant and $T$ and $\alpha$ are the temperature and the heating rate, respectively, corresponding to the value of the crystallized fraction, $x$.

The value of $x$ at a specific temperature can be determined from the DTA curves [42] by the ratio $A_{T} / A$. Here, $A$ is the total area of the crystallization peak between temperature $T_{i}$ (where crystallization begins) and temperature $T_{f}$ (where the crystallization is completed) and $A_{T}$ is the area between $T_{i}$ and $T$, as shown schematically in Figure 8. The graphical representation of $x$ as a function of $T$ shows typical sigmoid curves for different heating rates, as presented in Figure 9, indicating that the formation of the crystalline phase proceeds by a combination of nucleation and growth processes.

Using the experimental data presented in Figure 9, the plot of $\ln (\alpha)$ versus $1 / T$ for various values of $x(0.1<x<$ $0.9)$ was obtained, and the results are shown in Figure 10. The value of $E_{c}(x)$ was calculated from the slope.

Figure 11 shows the variation of $E_{c}(x)$ versus $x$ for the studied glass. It is observed that for the exothermal peak of all samples, corresponding to $\mathrm{Fe}_{3}\left(\mathrm{PO}_{4}\right)_{2}, E_{c}(x)$ is high during the initiation of the crystallization process and then it decreases. In addition, it is confirmed that the activation energies of PFTL2 and PFTL3 are lower than that of PFTL1.
This means that the crystal phases of PFTL2 and PFTL3 are more easily formed than that of PFTL1, and these results support the SEM and hydrophobicity results given above. By calculating the activation energy for crystallization, we think that PFTL2 and PFTL3 had lower hydrophobicity than PFTL1 owing to the increase in the size of their surface crystal phase structures and the corresponding reduced fraction of intergranular surface voids because of their lower activation energies.

\section{Conclusions}

This study analyzed the effect of the addition of $\mathrm{Li}_{2} \mathrm{O}_{3}, \mathrm{TiO}_{2}$, and $\mathrm{Fe}_{2} \mathrm{O}_{3}$ on the crystallization behavior of a $\mathrm{P}_{2} \mathrm{O}_{5}-\mathrm{CaO}-$ $\mathrm{SiO}_{2}-\mathrm{K}_{2} \mathrm{O}$ glass system and the effect of the crystallization of glass frit on the roughness and hydrophobicity of the coated glass surface.

We confirmed through XRD and DTA results that crystallization of $\mathrm{P}_{2} \mathrm{O}_{5}-\mathrm{CaO}-\mathrm{SiO}_{2}-\mathrm{K}_{2} \mathrm{O}$ glass occurs with the addition of $\mathrm{Li}_{2} \mathrm{O}_{3}, \mathrm{TiO}_{2}$, or $\mathrm{Fe}_{2} \mathrm{O}_{3}$. In addition, through DTA analysis, it was confirmed that $T_{g}$ decreases with the addition of $\mathrm{Fe}_{2} \mathrm{O}_{3}$ or $\mathrm{TiO}_{2}$, which indicates that $\mathrm{Fe}_{2} \mathrm{O}_{3}$ and $\mathrm{TiO}_{2}$ act as network modifiers in phosphate glasses and weaken the glass structure. The surfaces of PFTL1- 3 heated at $800^{\circ} \mathrm{C}$ for $5 \mathrm{~min}$ presented a cell-like microstructure in which we observed nanostructures owing to the crystallization of graftonite and trilithium diiron(III) tris[phosphate(V)]. This hierarchical structure is similar to those found on the surfaces of some hydrophobic leaves. For these two reasons (adding $\mathrm{Fe}_{2} \mathrm{O}_{3}$ and $\mathrm{TiO}_{2}$, which act as network modifiers, and broken $\mathrm{P}-\mathrm{O}-\mathrm{P}$ bonding, which increases the surface morphology), the hydrophobicity increases in accordance with the degree of crystallization of the $\mathrm{Li}_{2} \mathrm{O}_{3^{-}}, \mathrm{TiO}_{2^{-}}$, and $\mathrm{Fe}_{2} \mathrm{O}_{3}$-doped $\mathrm{P}_{2} \mathrm{O}_{5}-\mathrm{CaO}-\mathrm{SiO}_{2}-\mathrm{K}_{2} \mathrm{O}$ glasses. However, the contact angle of the surfaces of these glasses with water never exceeded $90^{\circ}$, which is the general standard of hydrophobicity. We think this is owing to the particular characteristics of the phosphate groups, which are strongly hydrophilic. Through this study, we confirmed the possibility of developing inorganic and hydrophobic coating materials using the crystallization of glass. In addition, we established the need for additional research to overcome the compositional limitations of phosphate glasses to express hydrophobicity with existing hydrophobic coating materials.

\section{Conflict of Interests}

The authors declare that there is no conflict of interests regarding the publication of this paper.

\section{Acknowledgments}

This research was financially supported by the Ministry of Education, Science and Technology (MEST) and National Research Foundation of Korea (NRF) through the Human Resource Training Project for Regional Innovation. 


\section{References}

[1] E. Celia, T. Darmanin, E. Taffin de Givenchy, S. Amigoni, and F. Guittard, "Recent advances in designing superhydrophobic surfaces," Journal of Colloid and Interface Science, vol. 402, pp. 1-18, 2013.

[2] V. A. Ganesh, H. K. Raut, A. S. Nair, and S. Ramakrishna, "A review on self-cleaning coatings," Journal of Materials Chemistry, vol. 21, no. 41, pp. 16304-16322, 2011.

[3] Y. Y. Yan, N. Gao, and W. Barthlott, "Mimicking natural superhydrophobic surfaces and grasping the wetting process: a review on recent progress in preparing superhydrophobic surfaces," Advances in Colloid and Interface Science, vol. 169, no. 2, pp. 80-105, 2011.

[4] Z. G. Guo, W. M. Liu, and B.-L. Su, "Superhydrophobic surfaces: from natural to biomimetic to functional," Journal of Colloid and Interface Science, vol. 353, no. 2, pp. 335-355, 2011.

[5] Y. Zhou, M. Li, X. Zhong, Z. Zhu, P. Deng, and H. Liu, "Hydrophobic composite coatings with photocatalytic selfcleaning properties by micro/nanoparticles mixed with fluorocarbon resin," Ceramics International, vol. 41, no. 4, pp. 53415347, 2015.

[6] J. Zhao, Z. Li, M. Zhang, and A. Meng, "Super-hydrophobic surfaces of $\mathrm{SiO}_{2}$-coated $\mathrm{SiC}$ nanowires: fabrication, mechanism and ultraviolet-durable super-hydrophobicity," Journal of Colloid and Interface Science, vol. 444, pp. 33-37, 2015.

[7] H. C. Barshilia, N. Selvakumar, N. Pillai, L. M. Devi, and K. S. Rajam, "Wettability of $\mathrm{ZnO}$ : a comparison of reactively sputtered; Thermally oxidized and vacuum annealed coatings," Applied Surface Science, vol. 257, no. 9, pp. 4410-4417, 2011.

[8] J. Seo, S. Lee, J. Lee, and T. Lee, "Guided transport of water droplets on superhydrophobic-hydrophilic patterned Si nanowires ," ACS Applied Materials \& Interfaces, vol. 3, no. 12, pp. 4722-4729, 2011.

[9] R. Taurino, E. Fabbri, M. Messori, F. Pilati, D. Pospiech, and A. Synytska, "Facile preparation of superhydrophobic coatings by sol-gel processes," Journal of Colloid and Interface Science, vol. 325, no. 1, pp. 149-156, 2008.

[10] B. Balu, V. Breedveld, and D. W. Hess, "Fabrication of 'rolloff' and 'sticky' superhydrophobic cellulose surfaces-via plasma processing," Langmuir, vol. 24, no. 9, pp. 4785-4790, 2008.

[11] N. L. Tarwal and P. S. Patil, "Superhydrophobic and transparent $\mathrm{ZnO}$ thin films synthesized by spray pyrolysis technique," Applied Surface Science, vol. 256, no. 24, pp. 7451-7456, 2010.

[12] J. J. Reinosa, J. J. Romero, M. A. de la Rubia, A. del Campo, and J. F. Fernández, "Inorganic hydrophobic coatings: surfaces mimicking the nature," Ceramics International, vol. 39, no. 3, pp. 2489-2495, 2013.

[13] P. Palmisano, P. Faraldi, D. Fino, and N. Russo, "Household oven self-cleaning surfaces via catalytic thermal oxidation," Chemical Engineering Journal, vol. 154, no. 1-3, pp. 251-257, 2009.

[14] P. Palmisano, S. P. Hernandez, M. Hussain, D. Fino, and N. Russo, "A new concept for a self-cleaning household oven," Chemical Engineering Journal, vol. 176-177, pp. 253-259, 2011.

[15] V. Dave, H. O. Gupta, and R. Chandra, "Nanostructured hydrophobic DC sputtered inorganic oxide coating for outdoor glass insulators," Applied Surface Science, vol. 295, pp. 231-239, 2014.

[16] H. Hosono and $\mathrm{Y}$. Abe, "Fast lithium conducting glass-ceramics in the $\mathrm{Li}_{2} \mathrm{O}-\mathrm{CaO}-\mathrm{TiO}_{2}-\mathrm{Al}_{2} \mathrm{O}_{3}-\mathrm{P}_{2} \mathrm{O}_{5}$ system," Solid State Ionics, vol. 44, no. 3-4, pp. 293-297, 1991.
[17] H. Hosono and Y. Abe, "Porous glass-ceramics with a skeleton of the fast-lithium-conducting crystal $\mathrm{Li}_{1+x} \mathrm{Ti}_{2-x} \mathrm{Al}_{x}\left(\mathrm{PO}_{4}\right)_{3}$," Journal of the American Ceramic Society, vol. 75, no. 10, pp. 2862-2864, 1992.

[18] B. K. Money and K. Hariharan, "Lithium ion conduction in lithium metaphosphate based systems," Applied Physics A, vol. 88, no. 4, pp. 647-652, 2007.

[19] X. Xu, Z. Wen, X. Yang, J. Zhang, and Z. Gu, "High lithium ion conductivity glass-ceramics in $\mathrm{Li}_{2} \mathrm{O}-\mathrm{Al}_{2} \mathrm{O}_{3}-\mathrm{TiO}_{2}-\mathrm{P}_{2} \mathrm{O}_{5}$ from nanoscaled glassy powders by mechanical milling," Solid State Ionics, vol. 177, no. 26-32, pp. 2611-2615, 2006.

[20] R. C. Lucacel, M. Maier, and V. Simon, "Structural and in vitro characterization of $\mathrm{TiO}_{2}-\mathrm{CaO}-\mathrm{P}_{2} \mathrm{O}_{5}$ bioglasses," Journal of NonCrystalline Solids, vol. 356, no. 50-51, pp. 2869-2874, 2010.

[21] N. A. Ghoneim, A. M. Abdelghany, S. M. Abo-Naf, F. A. Moustafa, and K. M. Elbadry, "Spectroscopic studies of lithium phosphate, lead phosphate and zinc phosphate glasses containing $\mathrm{TiO}_{2}$ : effect of gamma irradiation," Journal of Molecular Structure, vol. 1035, pp. 209-217, 2013.

[22] H. A. Elbatal, A. M. Abdelghany, F. H. Elbatal, K. M. Elbadry, and F. A. Moustaffa, "UV-visible and infrared absorption spectra of gamma irradiated $\mathrm{CuO}$-doped lithium phosphate, lead phosphate and zinc phosphate glasses: a comparative study," Physica B: Condensed Matter, vol. 406, no. 19, pp. 3694-3703, 2011.

[23] Y. Daiko, H. Yajima, and T. Kasuga, "Preparation of porous titanium phosphate glass-ceramics for $\mathrm{NH}_{3}$ gas adsorption with self-cleaning ability," Journal of the European Ceramic Society, vol. 28, no. 1, pp. 267-270, 2008.

[24] S. V. Dorozhkin, "Amorphous calcium (ortho)phosphates," Acta Biomaterialia, vol. 6, no. 12, pp. 4457-4475, 2010.

[25] S. A. M. Abdel-Hameed, M. A. Marzouk, and M. M. Farag, "Effect of $\mathrm{P}_{2} \mathrm{O}_{5}$ and $\mathrm{MnO}_{2}$ on crystallization of magnetic glass ceramics," Journal of Advanced Research, vol. 5, no. 5, pp. 543$555,2014$.

[26] A. Ananthanarayanan, G. P. Kothiyal, L. Montagne, and B. Revel, "MAS-NMR investigations of the crystallization behaviour of lithium aluminum silicate (LAS) glasses containing $\mathrm{P}_{2} \mathrm{O}_{5}$ and $\mathrm{TiO}_{2}$ nucleants," Journal of Solid State Chemistry, vol. 183, no. 6, pp. 1416-1422, 2010.

[27] E. Mohaghegh, A. Nemati, B. Eftekhari Yekta, S. Banijamali, and F. Rezaei, "Influence of $\mathrm{Fe}_{2} \mathrm{O}_{3}$ on non-isothermal crystallization kinetics and microstructure of lithium titanium phosphate glass-ceramics," Journal of Non-Crystalline Solids, vol. 408, pp. 130-136, 2015.

[28] H. Liu, Y. Wang, T. Wang, R. Yang, and S. Liu, "Enhanced surface crystallization of glass by adding traditional oxide nucleating agents," Ceramics International, vol. 40, no. 1, pp. 453-457, 2014.

[29] H. R. Ahmadi Mooghari, A. Nemati, B. Eftekhari Yekta, and Z. Hamnabard, "The effect of $\mathrm{SiO}_{2}$ and $\mathrm{K}_{2} \mathrm{O}$ on glass forming ability and structure of $\mathrm{CaO}-\mathrm{TiO}_{2}-\mathrm{P}_{2} \mathrm{O}_{5}$ glass system," Ceramics International, vol. 38, no. 4, pp. 3281-3290, 2012.

[30] J. Sułowska, I. Wacławska, and Z. Olejniczak, "Structural studies of copper-containing multicomponent glasses from the $\mathrm{SiO}_{2}$ $\mathrm{P}_{2} \mathrm{O}_{5}-\mathrm{K}_{2} \mathrm{O}-\mathrm{CaO}-\mathrm{MgO}$ system," Vibrational Spectroscopy, vol. 65, pp. 44-49, 2013.

[31] A. A. S. Lopes, R. C. C. Monteiro, R. S. Soares, M. M. R. A. Lima, and M. H. V. Fernandes, "Crystallization kinetics of a bariumzinc borosilicate glass by a non-isothermal method," Journal of Alloys and Compounds, vol. 591, pp. 268-274, 2014. 
[32] M. Erol, S. Kuchukbayrak, and A. Ersoy-Meriçboyu, "The application of differential thermal analysis to the study of isothermal and non-isothermal crystallization kinetics of coal fly ash based glasses," Journal of Non-Crystalline Solids, vol. 355, no. 9, pp. 569-576, 2009.

[33] T. Ozawa, "Calculating the phase transformation kinetics using impedance spectroscopy for Sb2Te3," Polymer, vol. 12, pp. 150$158,1971$.

[34] S. M. Salman, S. N. Salama, and H. A. Abo-Mosallam, "The effect of aluminum and germanium oxides on the crystallization process and magnetic properties of $\mathrm{Li}_{2} \mathrm{O}-\mathrm{Fe}_{2} \mathrm{O}_{3}-\mathrm{SiO}_{2}$ glass system," Ceramics International, vol. 41, no. 1, pp. 1521-1529, 2015.

[35] M. Navarro, E. Engel, J. A. Planell, I. Amaral, M. Barbosa, and M. P. Ginebra, "Surface characterization and cell response of a PLA/CaP glass biodegradable composite material," Journal of Biomedical Materials Research, Part A, vol. 85, no. 2, pp. 477486, 2008.

[36] E. A. Abou Neel, I. Ahmed, J. J. Blaker et al., "Effect of iron on the surface, degradation and ion release properties of phosphatebased glass fibres," Acta Biomaterialia, vol. 1, no. 5, pp. 553-563, 2005.

[37] E. A. Abou Neel, W. Chrzanowski, and J. C. Knowles, "Effect of increasing titanium dioxide content on bulk and surface properties of phosphate-based glasses," Acta Biomaterialia, vol. 4, no. 3, pp. 523-534, 2008.

[38] Z. Burton and B. Bhushan, "Surface characterization and adhesion and friction properties of hydrophobic leaf surfaces," Ultramicroscopy, vol. 106, no. 8-9, pp. 709-719, 2006.

[39] A. B. D. Cassie and S. Baxter, "Wettability of porous surfaces," Transactions of the Faraday Society, vol. 40, pp. 546-551, 1944.

[40] A. A. Abu-Sehly, S. N. Alamri, and A. A. Joraid, "Measurements of DSC isothermal crystallization kinetics in amorphous selenium bulk samples," Journal of Alloys and Compounds, vol. 476, no. 1-2, pp. 348-351, 2009.

[41] A. A. Joraid, S. N. Alamri, and A. A. Abu-Sehly, "Model-free method for analysis of non-isothermal kinetics of a bulk sample of selenium," Journal of Non-Crystalline Solids, vol. 354, no. 28 , pp. 3380-3387, 2008.

[42] A. Arora, E. R. Shaaban, K. Singh, and O. P. Pandey, "Nonisothermal crystallization kinetics of $\mathrm{ZnO}-\mathrm{BaO}-\mathrm{B}_{2} \mathrm{O}_{3}-\mathrm{SiO}_{2}$ glass," Journal of Non-Crystalline Solids, vol. 354, no. 33, pp. 3944-3951, 2008. 

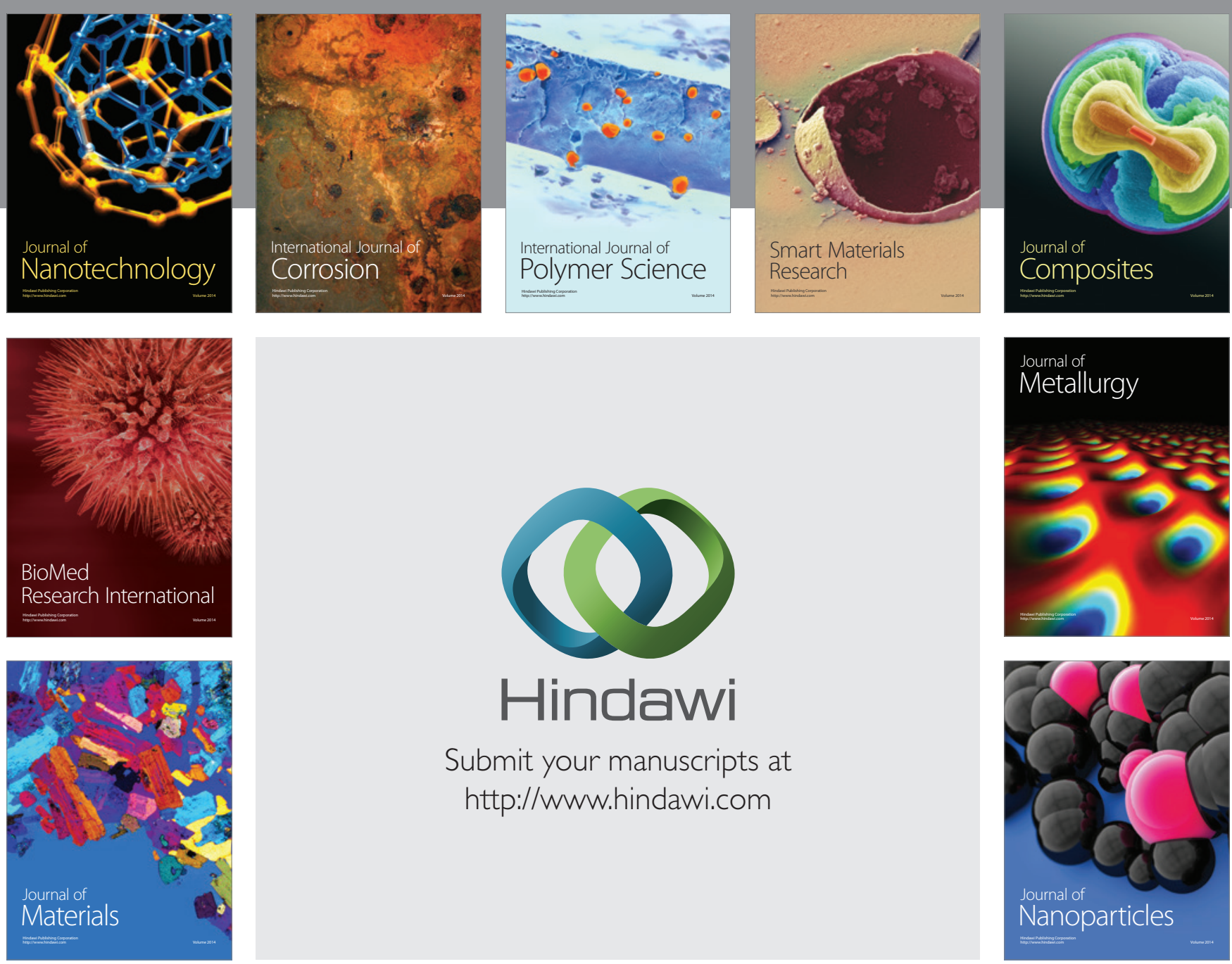

Submit your manuscripts at http://www.hindawi.com
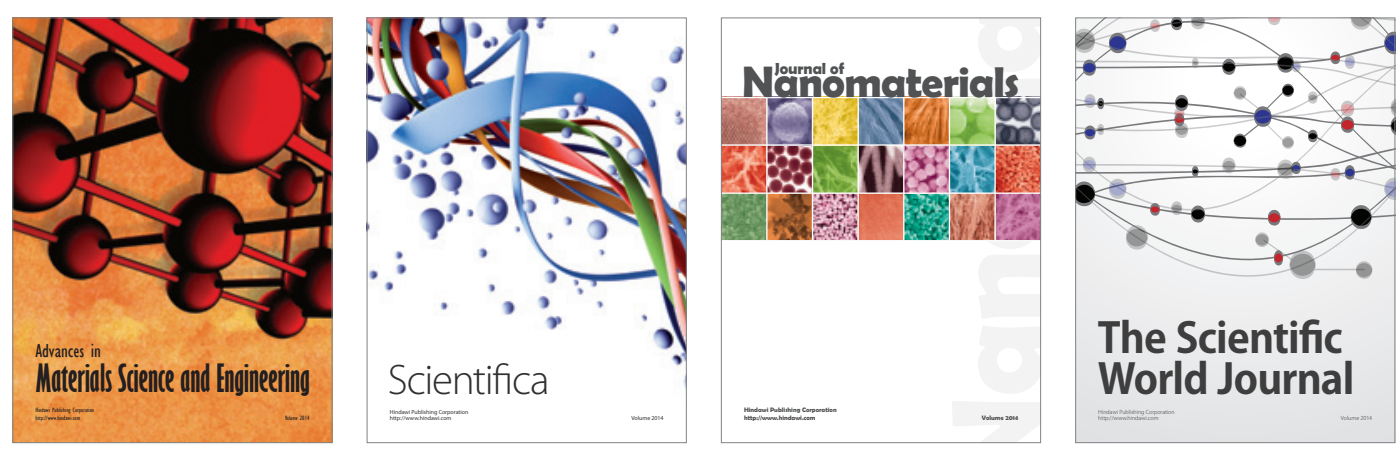

\section{The Scientific World Journal}
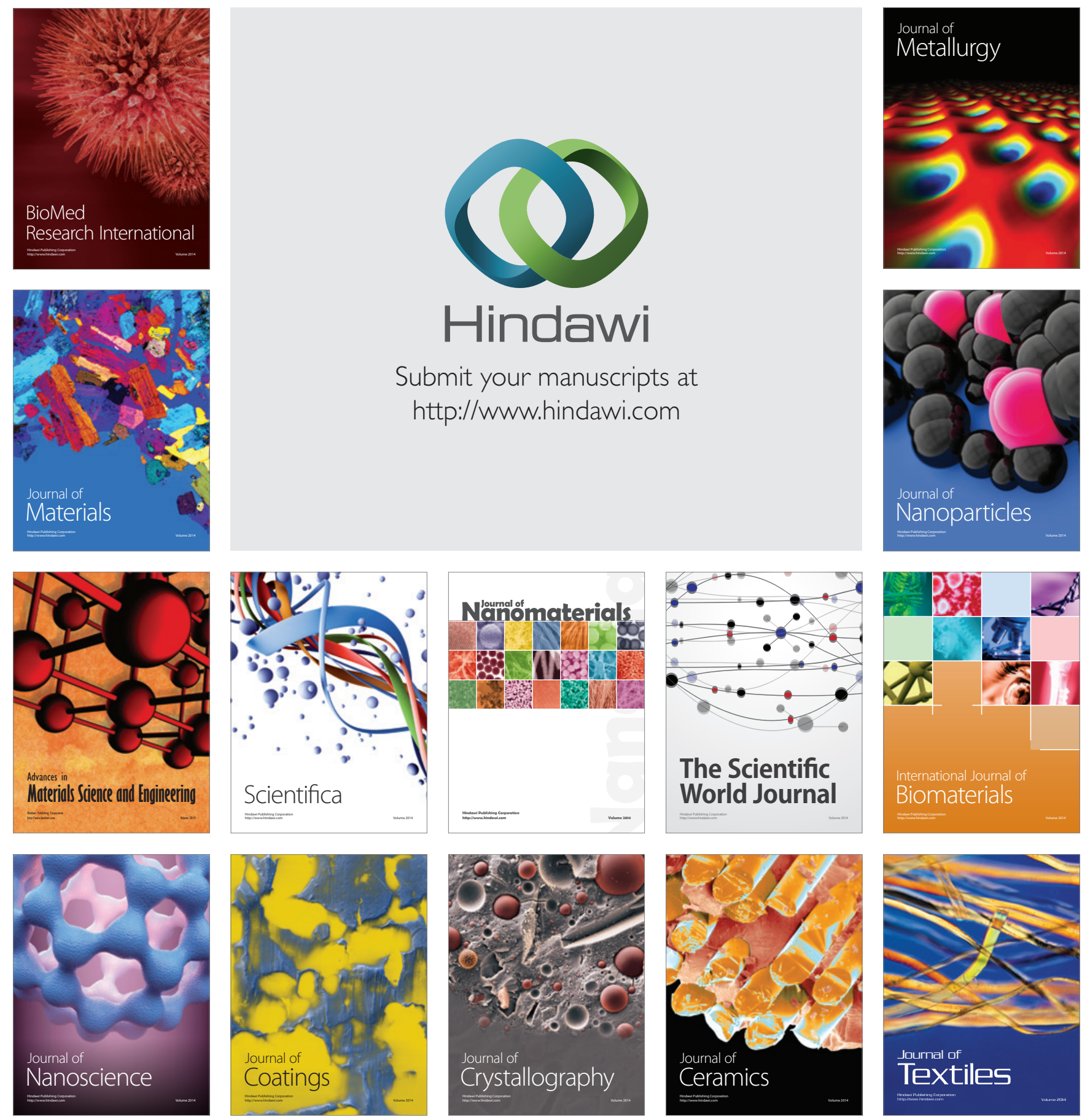